\title{
Impact of Law and Order in the Management of Corruption, Fraud and Cybercrime for Economic Development: The study of two African Nations (Nigeria and Malaysia).
}

\author{
Nwele, J. Obasi, PhD, LLB \\ Renaissance University, Enugu, Nigeria
}

\begin{abstract}
Corruption and Fraud has been an endemic problem in the global economic affairs for ages, and recently Cybercrime has joined the litany of the cankerworm that impede economic development and social tranquility of nations. To control and manage human resource capital, in relation to stock of or supply of money, materials, and other assets that can be drawn on by a person, organization or state, to establish an effective and viable economy, individuals, organizations and governments need to maintain a truly functional law and order. It is a fact that Africa (especially Nigeria and Malaysia) as a part of the world, especially in the new global politics tries to align to the protection of its environment against corruption and fraud. This study examines the level, and the indices of corruption and fraud in relation to law and order in African, especially in Nigeria and Malaysia. Primary and secondary data were used in this research, which aims at discovering appropriate measures to squarely or effectively address corruption, economic fraud and cybercrime in Africa. Binary logistic regression and chi-square were applied. The findings reveal that economic development, politics, democracy and rule of law has a nexus to addressing the complex nature of fighting corruption, fraud, and cybercrime in individual, organization, and government business management.
\end{abstract}

Keywords: Law, Corruption, Fraud, Cybercrime, Business Management, Africa, Nigeria, Malaysia, and Economic Development

\subsection{Understanding Financial Economics and Fraud}

\section{Introduction}

Societies are opening to debate and markets to individual initiatives; with entrepreneurship and privatization being encouraged. Economic development ideally, refers to the sustained, concerted actions of communities and policy makers that improve the standard of living and economic health of a specific locality or society. With major changes and new emphases appearing on the development scene of a new world where technologies are becoming widely available and management of government services gradually being relocated closer to the users. These are the lessons of economics.

This study deals with the economics of diagnosing corruption and fraud effects in a society, the cure or treatment of same, through effective and functional law. Economics is a branch of business studies that deals with all the aspects of a country's economy, such as how a country uses its resources, the outcome of investing in industries and/or financial products, including how much time labourers spend or devote to work and leisure, the effect of taxation on a population, and why businesses succeed or fail, "which brings the business manager to financial economics.' Like in business and marketing, economics is concerned with the realities of life under three concepts: What to produce, and in what quantity; How to produce it; and, for whom? Economics is a social science that study human behavior between ends and scarce means which have alternative uses.

Law

Law on its own is a body of official rules and regulations, generally found in constitutions, legislations, judicial opinion, and similar provisions that is used to govern a society and to control the behaviour of its members. The Nature and functions of law have varied throughout history. In modern societies, some authorized body such as a legislature or a court makes law. This law is backed by the coercive power of the state, which enforces the law by means of appropriate penalties or remedies. Legislation for behaviour warrants focus upon the legality of an action and not the morality of such action. This study seeks to examine the efficacy of the law that guarantees sustainable economic development and against corruption, fraud, and cybercrimes in a society.

\section{Corruption}

Corruption is a dishonest or *fraudulent conduct by those in power; this involves typically, bribery or the process by which an expression or word is changed from its original form to an erroneous order based form including putrefaction. 
Corruption is the misuse of public power (by any appointed civil servant or elected politician for private benefit or gain, and when the law brings down its harmer on corrupt persons and fraudsters, it can cost people their freedom, health, money, and sometimes even life.

"Corruption corrodes the fabrics of society and undermines people's trust in political and economic systems, institutions and leaders" - (transparency international).

\section{Fraud}

Fraud as a name and an action is described by many words like extortion, cheat, embezzlement, swindle, scam, double-cross, ploy, hoodwink, hoax, (and in Nigeria -419), and corruption, including perversion of concealment of truth, to gain unlawful or unfair advantage over someone or organization or state. Today in many nations of Africa, especially in Nigeria and Malaysia, corruption and fraud has eaten deep into the caprices of governments, and non-government institutions, and even in individual relations that it has become systemic. As against exploitation of occasional opportunities, a systemic corruption occurs when corruption become an integrated part or essential aspect of the economic, social and political system of a society- this is presently what is obtainable in Nigeria as against Malaysia.

Few years ago, Malaysia came to Nigeria to be assisted with ten-era oil palms for commercial palm production. According to Shola Adebowale in his 'The Miracle Tree Between Nigeria and Malaysia;' "Few years ago Malaysia got its tenera oil palms from Nigeria. Today Malaysia is the world's biggest palm oil producing country, accounting for about half of the world production. This was as a result of Malaysia's research and development (R\&D) program in oil palm breeding, by its Department of Agriculture's exchange programe with Nigeria in the 1960s.

By 1995 Malaysia had become the world's largest producer with 51\% of world production. This is because Malaysia had control on the indices of corruption.In its legal definition, fraud is false representation of a matter of fact, whether by words or by conduct i.e. by misleading or false allegations. These also include the concealment of what ought to have been disclosed, that deceives and, is intended to deceive another so that that individual act upon his or her detriment - West's Encyclopedia of American Law (2008).

Fraud is advance-fee scam where one is asked to help transfer money out of another country in return for a percentage of the money transferred or to pay in money for an expected supply that will never be supplied. Fraud schemes are used by fraudsters to commit corrupt activities

\section{Cybercrime}

Cybercrime is any unlawful or criminal activity that involves a computer or internet or network connected devices, such as mobile phone as the tool or device used or in use by the agent of the crime or fraudster as the case may be. It is any crime committed using a computer network or hardware device.Cybercrime covers a wide range of different attacks, which deserve a unique approach to improving computer safety and protecting the individual or organization or state. This involves extortion, planning or carrying out terrorist activities, blackmail, manipulation, etc.

This study sets to address the problems of corruption, fraud, cybercrime, and inclusive growth for inclusive development, through structured democracy that gives birth to credible and worthy leaders and good governance, in Africa.

\section{Review of Related Literature \\ 2.1. Law and Business}

Every business need to deal with legal matters and, because of the nature of legal tasks as daunting issue, a solicitor or solicitors may be required to help with legal matters that may arise. The risk of business disputes, fines, prosecution or being sued may be avoided by the consideration of the business legal obligations and taking early preventive measures.

Business or Mercantile Law is a body of law that relates to commerce and business transactions. It includes laws that pertain to sales of goods; negotiable instruments, such as cheques and promissory notes; carriage by land and sea; insurance; brokerage; guarantee and shipping.

Law is not completely a matter of human enactment as it also includes 'natural law.' It is said that the best-known version of the law of nature is, that God's law is supreme and has had considerable influence in the legal system of the United States of America and other Western societies.

Formal legal rules and actions are usually distinguished from other means of social control and guides for behaviours such as mores, morality, public opinion, and other instincts of custom and tradition. 


\subsection{Corruption and Fraud in Business Management in Africa}

According to Andrew Bettie, "A true history of fraud is traced to 300B.C. when Greek merchant, Hegestratos got a large insurance policy known as bottomry. In the deal the merchant borrowed money and agrees to pay it back with interest when the cargo, corn is delivered. If the loan is not paid back it is agreed, the lender can acquire the boat and its cargo."

He gestratos planned to sink his empty boat, keep the loan and sell the corn. This did not work out, and he got drowned trying to escape his crew passengers when they caught him in the act. This is the first recorded incident of fraud as there may have been other ones since the beginning of Commerce. A few years after America officially became a nation; the first fraud occurred in 1792 of trading and bond scandal.

Ulysses S. Grant was a former President and a renowned war hero. He only wanted to help his son, Buck, succeed in business, but ended up causing a financial panic through misrepresentation or identity fraud.

Report: Trinity University by Bob Jensen one of the best known fraud was the 1626 purchase of Manhattan Island for trinkets value at 60 guilders (approximately \$24), and perpetrated by Carnarsie Indians from Brooklyn - www.trinity.edu/rjensen/FraudA

Government acquisitions of land have afforded expanding opportunities for legislators (or their agents) and government bureaucrats to accept bribes and otherwise collaborate with land swindlers.

In 1787 fewer than 40 corporations operated in the US, and contract with government to build roads, bridges, canals, dams, and other public projects. Many of the projects were burdened with bribes, kickbacks, and inflated prices.

Financial Crime and Fraud Management

History is full of Scams and Frauds that removed billions of dollars from the pockets of governments and investors and destroyed entire economies

The most famous forgeries according to Guardian.co.Uk have taken place in the $20^{\text {th }}$ century, by "Etruscan" terracotta warriors that were sold to the New York met between 1915 and 1921.

\section{Fraud Laws}

One of the laws that control fraud offences is the Advance Fee Fraud and other Fraud Related Offenses Act 2006 - Laws of the Frederation of Nigeria

1) Notwithstanding anything contained in any other enactment or law, any person who by any false pretence, and with intent to defraud

a) obtains, from any other person, in Nigeria or in any other country for himself or any other person;

b) induces any other person, in Nigeria or in any other country, to deliver to any person; or

c) obtains any property, whether or not the property is obtained or its delivery is induced through the medium of a contract induced by the false pretence, commits an offence under this Act.

2) A person who by false pretence, and with the intent to defraud, induces any other person, in Nigeria or in any other country, to confer a benefit on him or on any other person by doing or permitting a thing to be done an understanding that the benefit has been or will be paid for commits on offence under this Act.

3) A person who commits an offence under subsection (1) or (2) of this section is liable an conviction to imprisonment for a term of not more than 20 years and not less than seven years without the option of a fine.

\subsection{What the Law Says About Fraud}

While the exact wording of fraud charges varies among state and federal laws, the essential elements needed to prove a fraud claim in general include:

1) a misrepresentation of a material fact;

2) by a person or entity who knows or believes it to be false;

3) to a person or entity who justifiably relies on the misrepresentation; and

4) actual injury or loss resulting from his or her reliance.

Most states require that each element be proven with "particularity" - meaning that each and every element must be separately proven for a fraud charge to stand.

In law, fraud is deliberate deception to secure unfair or unlawful gain, or to deprive a victim of a legal right. Fraud itself can be a civil wrong (i.e., a fraud victim may sue the fraud perpetrator to avoid the fraud and/or recover monetary compensation), a criminal wrong (i.e., a fraud perpetrator may be prosecuted and imprisoned by governmental authorities) or it may cause no loss of money, property or legal right but still be an element of another civil or criminal wrong. The purpose of fraud may be monetary gain or other benefits, such as obtaining a driver's license or qualifying for a mortgage by way of false statements.

Laws against fraud vary from state to state, and can be criminal or civil in nature. Criminal fraud requires criminal intent on the part of the perpetrator, and is punishable by fines or imprisonment. Civil fraud, on the other hand, applies more broadly to circumstances where bad-faith is usually involved, and where the 
penalties are meant to punish the perpetrator and put the victim back in the same position before the fraud took place.

A hoax is a distinct concept that involves deliberate deception without the intention of gain or of materially damaging or depriving a victim. A corrupt practice include: the offering of and/or giving, receiving or soliciting, directly or indirectly, anything of value to influence improperly the actions of another party, including artificially inflating project financing (and execution) costs - Nwele (2013).

\subsection{Empirical Analysis \\ Fraud Laws}

Fraud Law covers a broad range of crimes and civil tort actions that address situations in which a person wrongfully obtains money, property, or other benefits by deceit. In the criminal context, fraud is typically charged as a felony, meaning that a conviction can result in a year or more of incarceration. Criminal penalties can also include statutory fines, restitution (victim reimbursement), community service, as well as the loss of civil rights associated with a felony conviction. In civil court, financial compensation is generally the plaintiff's sole remedy. Fraud cases can be brought in either state or federal court.

The sale of the Roman Empire in (193 A.D.) by a Praetorian Guard, to Julianus (at 250 gold pieces to every of the army member; all amounting to equivalent of today's \$1 billion) as highest bidder, this also is fraud. In 1496, Michelangelo faked a piece of Sculpture and sold it to Cardinal Riario of San Giorgio, again, it is fraud.

\section{Business Prudence Analysis}

Prudence management requires that those with responsibility to invest money for others should act with intelligence of discretion, prudence, and regard for the safety of capital as well as income.

Prudence as a principle requires organizations or companies to report on their balance sheet, the value of their assets and liabilities at their least favorable valuation. Prudence demands that revenue is not recognized unless it is certain, while expense are recognized while they are probable - meaning that income/expense recognition and projections should be realistic.

On the concept, investments are recorded at the value, of the lowest rate; this is because it is only after selling of position that the company or organization recognizes any gains. Similarly, inventory of raw materials is valued at the lowest of cost of purchase and market price, while inventory of finished goods are recorded at the lowest of cost of production and selling price. All real-estate assets are recorded at cost and any increase in value is not accounted for till the sale of the asset, but any significant loss of value is reported immediately.

The multi-faceted nature of business, law and finance raises a number of complex social-magma issues. For example, how do we handle activities that have to do with business and economic policy relationship with financial management, including communication economics and politics? How do we solve the many problems of resource mobilization and inclusion for inclusive growth of an economy?

\section{Discussion}

In the Nation newspaper - September 11, 2016, it is reported, Nigeria's inaction delays recovery of $\$ 85$ million ex-minister's loot. The United Kingdom is waiting for Nigeria to claim an $\$ 85$ million loot recovered from a former petroleum minister, Dan Etete, according to the Evening Standard of London.

The newspaper reported that federal government's failure to send a proceeds-of-crime submission to the judge of a UK Court is stalling the recovery of the money which is frozen in a NatWest bank account in London.

The $\$ 85 \mathrm{~m}$ is believed to be part of the proceeds from the award of the licence of OPL245 - an oilfield containing an estimated nine billion barrels of crude - made by Etete to Malabu Oil \& Gas, for \$20 million, said to be tiny fraction of its real value.

The licence award sparked a multitude of legal suits between Shell and Malabu over the ownership of the field only for federal government to sell the field to Eni and Shell.

$\$ 1.09$ billion of the money paid by the two companies later found its ay to Malabu. Shell and Eni claimed ignorance of who paid the $\$ 1.09$ billion to Malabu.

The newspaper said investigations at Britain's National Crime Agency who are trying to probe the alleged laundering of OPL 245, money through London banks and properties are frustrated by alleged inaction from Nigeria's end.

The Malabu Oil deal is believed to have led to the siphoning off of $\$ 1$ billion from a $\$ 1.3$ billion international investment in the lucrative oil block through 'fees' to Etete's company and middlemen.

High Court Judge, Mr Justice Edis said: "Given the large sums of money involved that are effectively paid to former minister to a bank account in the Middle East, the whole exercise is backed by murky instruction." 
The law has been specific about the management of fraud and corruption crimes, for example, in Nigeria there is 'the economic and financial crimes commission (EFCC),' 'the independent corrupt practices commission and other related offences commission (ICPC), etc. Fraud poses the risk of both financial loss and personal danger to their victims.

Recently, the Cameroonian government started a massive crackdown on Pentecostal churches in the country as President Paul Biya accused them of threatening the security of the country, especially in relation to financial crimes and fraud.

Tendai Ruben Mbofana is a Social Justice activist and commentator, who in a recent article argued that, the "African Union is nothing more than a dictators' club, which seeks to serve and protect the interests of those in power, at the expense the suffering ordinary people."

The AU succeeded the Organization of African Unity (OAU) in 2001 and till today, still lack vision and creativity. The majority of the estimated 800 million African people are disillusioned and desperate because the continent is on the bottom line of human development indicators, striken with a metaphor for poverty, disease, unemployment, corruption and management. The bad governance practice have made the continent to face the greatest human displacement among all the world's regions.

\section{Conclusion}

The perspective of corruption encompasses undue influence over public policies, institutions, laws and regulations by vested private interests at the expense of the public interest. Cultural change, rather than legal change is necessary to impede corrupt behavior.

Political Corruption, when the laws and the regulations are abused by the rulers, side-stepped, ignored, or even tailored to fit their interests. That is by interpretation, when then the legal bases, against which corrupt practices are usually evaluated and judged, are week and further subject to ridicule, encroachment, and downright by the rulers, needs to be properly checked and prudently controlled in Africa for inclusive development to take its place in governance.

\section{Recommendations}

We need to use experts in \{Cyber security\} to fight fraud and corruption that occur through cybercrime, including research experts working on technical protection against 'Trojan horse virus, and others.

We need sound mechanisms for communication and participation, a safe and effective work environment, developing mutual trust in their reliability. The law must be made to be effective in the control of every aspect of corruption, fraud, cybercrime, and the punishment for offenders at every level of society.

There is a great need for public office holders to eschew greed and envy, which causes fraud, corruption, abuse to the rule of law, financial disorder, and business failure. All these attributes and variables make up the factors that lead to economic recession and orgy of political crisis.

African leaders need to be visionary and creative, with inclusive growth to achieve inclusive development and stability.

\section{References}

[1] Beattie, Andrew, 2016, Fraud History ,(www.investopedia.com/articles/finance)

[2] Clunas, Craig, et al. “china.”Microsoft@Encarta@2009 ‘(DVD)’ Redmond, WA; Microsoft corporation, 2008.

[3] Colander, David C. (2004), Economics, Fifth edition, McGraw Hill, Irwin; business unit, McGraw-Hill Companies, Inc, 1221 Avenue of the Americans, New York, NY 10020

[4] Ejime Paul (2016), The Guardian News on 'African Union deserves visionary, dynamic leadership,' September 8, 2016; copyright (C) 2016 Guardian Newspapers

[5] Elaine Byrne (2007), The Moral and Legal Development of Corruption: Nine-teenth and Twentieth Century Corruption in Ireland $\mathrm{PhD}$ Thesis, University of Limerick.

[6] Jenson Bob, www.trinity.edu/rjensen/Fraud

[7] Nwele, JO (2013), "Credit and Risk Management in Business Administration: the Problem and Prospects," an unpublished seminar paper, presented at 'Training the Trainers Workshop, Bauchi, 2013.

[8] Robert, Walter "Law.”Microsoft@Encarta@2009(DVD), Redmond, WA; Microsoft Corporation, 2008.

[9] Shola A. (2012), “The Miracle Tree Between Nigeria and Malaysia,”@dailypostngr - October 15, 2012

[10] www.http://people.cognate.edu/mjohnson...

[11] West's Encyclopedia of American Law, edition 2. Copyright 2008, The Gate Group, Inc. All rights reserved.

[12] Whitney Sherry, June, 2016, www.oxfordhandbooks.com/...

[13] World Economic Forum, Global Competitiveness Report 2004/2005 - D. Kanfmann, Sept. 2006 on Corruption, Governance and Security and Social foundations for Institutional Reform - Michael Johnston.

[14] www.Guardian.co.Uk

[15] www.Legal-dictionary.thefreediction...

[16] www.transparency.org/... 


\section{Contribution/Originality:}

This study contributes to the assessment of the existing level of the administration of law and order on corruption, fraud, cybercrime management in Africa, especially in Nigeria and Malaysia. This study projects new aggregate level distinction on research matter analysis of corruption, fraud, cybercrime and administration of law in business management, including the first grade logical analysis of economic growth and inclusive development. This study intends to address critically, the mafia's corruption in societies - i.e. diagnose it so we can cure or treat it. 